\title{
Retention of visible implant tags in small rockpool fishes
}

\author{
Shane P. Griffiths* \\ Environmental Science, University of Wollongong, Northfields Avenue, Wollongong, New South Wales 2522, Australia
}

\begin{abstract}
Retention and associated fish mortality of visible implant alphanumeric (VIA) and fluorescent elastomer tags was assessed in 2 Australian intertidal rockpool fishes, Girella elevata (Girellidae) and Bathygobius cocosensis (Gobiidae). Mean retention of VIA and elastomer tags after $90 \mathrm{~d}$ was $32 \pm$ $20 \%$ and $77 \pm 19 \%$, respectively. After $90 \mathrm{~d}$ the fish mean mortality from VIA tags $(20 \pm 5 \%)$ was significantly higher than from elastomer tags $(7 \pm 2 \%)$ and untagged control groups $(11 \pm 2 \%)$. Elastomer tags appear most suitable for marking batches of fish of various size, while VIA tags appear suitable for identification of larger individuals of species such as many gobies that have adequate transparent tissue for tag recognition.
\end{abstract}

KEY WORDS: Bathygobius cocosensis - Elastomer · Girella elevata $\cdot$ Girellidae $\cdot$ Gobiidae $\cdot$ Intertidal $\cdot$ Tidepool

Resale or republication not permitted without written consent of the publisher

Tagging is a widely used method for estimating growth, survival, and mortality, as well as monitoring the movements of fishes and members of other taxa. The development of small implant tags (e.g. visible implant, passive integrated transponder [PIT] and coded wire tags [CWT]) has allowed ichthyologists to study fish considered too small to tag with conventional external tags, such as T-bar and spaghetti tags. Visible implant tags offer the advantages of being small, inexpensive and externally recognised allowing repeated observations of individuals without being sacrificed to retrieve tags (i.e. CWT).

Visible implant alphanumeric (VIA) and visible implant fluorescent elastomer (VIFE) tags manufactured by Northwest Marine Technology are 2 types of

*Present address: CSIRO Marine Research, PO Box 120, Cleveland, Queensland 4163, Australia.

E-mail: shane.griffiths@csiro.au visible implant tag that have been successfully used for marking small fishes in both freshwater (Blankenship \& Tipping 1993, Dewey \& Zigler 1996, Halls \& Azim 1998) and marine environments (Forrester 1995, Willis \& Babcock 1998, Malone et al. 1999). However, the present study is apparently the first study that assessed the utility of visible implant tags for tagging intertidal fishes. VIA tags are small $(1.0 \times 2.5 \mathrm{~mm})$ polyester pieces imprinted with alphanumeric codes that are externally visible when implanted into transparent tissue, permitting identification of individuals. Elastomer tagging involves injecting a fluorescent liquid elastomer into transparent tissue that sets to form a permanent, biocompatible mark, which is useful for identifying batches or cohorts of fish.

Tagging studies of intertidal rockpool fishes are relatively few, mainly owing to their small size and subsequent difficulty in marking (Gibson 1999), but with use of visible implant tags more accurate study of their growth and movements may be possible. The present study assessed the retention of VIA and elastomer tags and associated mortality rates for 2 common Australian intertidal rockpool fishes, Girella elevata and Bathygobius cocosensis, under laboratory conditions before undertaking field studies with these species.

Materials and methods. Fish were collected from rockpools in the Illawarra region $\left(34^{\circ} 58^{\prime} \mathrm{S}, 150^{\circ} 93^{\prime} \mathrm{E}\right)$, New South Wales, Australia, and transported to 6 flowthrough seawater aquaria where they were allowed to acclimate for 3 to $8 \mathrm{wk}$. In preparation for tagging, fish were anaesthetised in a $30 \mathrm{mg} \mathrm{l}^{-1}$ solution of clove oil using the methods of Griffiths (2000).

VIA and elastomer tags were implanted into the transparent cheek tissue of Bathygobius cocosensis, but since Girella elevata have few suitable tag locations due to dark skin pigmentation, VIA and elastomer tags were inserted into the semi-transparent tissue in the nape and cheek, respectively. Fluorescent 
yellow VIA tags were implanted with a syringe-like applicator. Fluorescent orange and red elastomer tags were implanted using a $0.3 \mathrm{cc}$ syringe following the directions of Northwest Marine Technology. All fish were measured (total length [TL] in $\mathrm{mm}$ ) and weighed (to the nearest $0.1 \mathrm{~g}$ ) during the tagging procedure and again after 15, 30, 60 and $90 \mathrm{~d}$, where the presence and readability of a tag were also recorded. Number and sizes of individuals of each species with each tag type is shown in Table 1, although it is important to note that fish tagged with VIA tags were generally larger than elastomer-tagged fish. As a result, it is possible that differences observed between tag treatments are due in part to differences in retention by differently sized fish.

Six aquaria maintained at the same seawater temperature $\left(17\right.$ to $\left.21^{\circ} \mathrm{C}\right)$ and flow rate were used for the laboratory experiment. Each aquarium was considered as a single replicate and contained all individuals of 1 of the 6 experimental groups (2 species: Girella elevata and Bathygobius cocosensis subjected to 3 tag types: VIA, Elastomer and Control). Fish were fed a selection of fresh Ulva, freeze-dried brine shrimp and krill or frozen blood worms every 2 to $3 \mathrm{~d}$.

ANOVA was used to test for differences in the mean retention among tag types and associated mortality rates of fish. Fish species was ignored as a factor in comparing retention and mortality among tag types. That is, retention percentages for both aquaria (1 of each species) of VIA and elastomer treatments were used as replicates. Sample size within the 2 treatments was 2. Similarly, mortality percentages for both aquaria (1 of each species) of VIA, elastomer and control treatments were used as replicates. Sample size within the 3 treatments was 2. Data were examined for

Table 1. Number, mean $( \pm 1 \mathrm{SE}$,$) weight (\mathrm{g})$ and total length $(\mathrm{mm})$, and length range of fish representing Girella elevata and Bathygobius cocosensis implanted with visible implant alphanumeric (VIA) and visible implant flourescent elastomer (VIFE) tags. The procedural control groups were left untagged but handled in a similar manner to the tagged fish

\begin{tabular}{|lcccc|}
\hline Species & $\begin{array}{c}\text { Number } \\
\text { tagged }\end{array}$ & $\begin{array}{c}\text { Length } \\
\text { range } \\
(\mathrm{mm})\end{array}$ & $\begin{array}{c}\text { Mean } \\
\text { length } \\
(\mathrm{mm})\end{array}$ & $\begin{array}{c}\text { Mean } \\
\text { weight } \\
(\mathrm{g})\end{array}$ \\
\hline VIA tags & 20 & $60-148$ & $84.9(5.8)$ & $11.5(2.9)$ \\
$\begin{array}{l}\text { Girella elevata } \\
\text { Bathygobius cocosensis }\end{array}$ & 25 & $43-64$ & $53.6(0.9)$ & $1.4(0.1)$ \\
VIFE tags & 12 & $47-69$ & $57.9(1.9)$ & $2.3(0.2)$ \\
$\begin{array}{l}\text { Girella elevata } \\
\text { Bathygobius cocosensis }\end{array}$ & 21 & $32-46$ & $39.8(0.9)$ & $0.6(0.1)$ \\
$\begin{array}{l}\text { Control } \\
\text { Girella elevata }\end{array}$ & 15 & $52-101$ & $76.2(4.4)$ & $9.3(1.8)$ \\
Bathygobius cocosensis & 23 & $34-59$ & $47.5(0.8)$ & $1.1(0.1)$ \\
\hline
\end{tabular}

homogeneity of variances using Cochran's test. No transformation of data was necessary. Tukey's honestly significant difference (HSD) test was used to determine significantly different means.

Results. Both VIA and elastomer tags were easily implanted for both species even when some fish were $<35 \mathrm{~mm}$ TL. Identification of tags with the naked eye was excellent for all species after $90 \mathrm{~d}$, although the use of either an infrared or black light in low light conditions significantly enhanced the readability of VIA tags.

There were considerable differences in retention rates among tag types, although the greatest proportion of fish generally lost VIA and elastomer tags $15 \mathrm{~d}$ and 60 to $90 \mathrm{~d}$ after tagging, respectively (Fig. 1). After $90 \mathrm{~d}$ the mean retention of VIA tags was $32 \pm 20 \%$, while higher retention rates $(77 \pm 19 \%)$ were recorded for elastomer tags (Fig. 1). ANOVA revealed that the mean retention rate was significantly higher for elastomer-tagged fish $\left(F_{1,2}=5.771, \mathrm{p}=0.043\right)$.

After $90 \mathrm{~d}$ the mean mortality of VIA-tagged fish was $20 \pm 5 \%$, which was higher than the mean mortality rates of both elastomer-tagged fish $(7 \pm 2 \%)$ and the control group (11 $\pm 2 \%$ ) (Fig. 2). ANOVA revealed that the overall mean mortality rates differed among tag types $\left(F_{2,3}=11.421, \mathrm{p}=0.002\right)$. Tukey's HSD test revealed that the mean mortality rate was significantly higher among VIA-tagged fish than among elastomertagged or control fish.

Discussion. High retention, low mortality and ease of identification of elastomer tags clearly indicate their higher suitability for marking intertidal rockpool fishes than VIA tags, particularly for fish of small sizes ( $<50 \mathrm{~mm} \mathrm{TL}$ ). Elastomer tags are useful for marking batches or cohorts of fish, and with the use of 2 elastomer colours 243 fish may be given unique markings (Dewey \& Zigler 1996). Since rockpool fishes normally have low densities within the intertidal zone, the use of elastomer tags for the purpose of identifying individuals may be adequate. Although VIA tags resulted in lower survivorship and retention rates, particularly for Girella elevata, their use for individual identification of gobies or similar species with adequate transparent tissue may be successful, although this should be restricted to fish $>50 \mathrm{~mm}$ TL. The potentially high trauma of injecting small fish with both relatively large VIA tags and the tag injector is another reason why only larger fish should be tagged. This was the reason for the larger sizes of fish tagged with VIA tags in the present study. However, it is also important to note that differences in retention and mortality rates among tag types may be partly due to differences in fish sizes among tag treatments. 


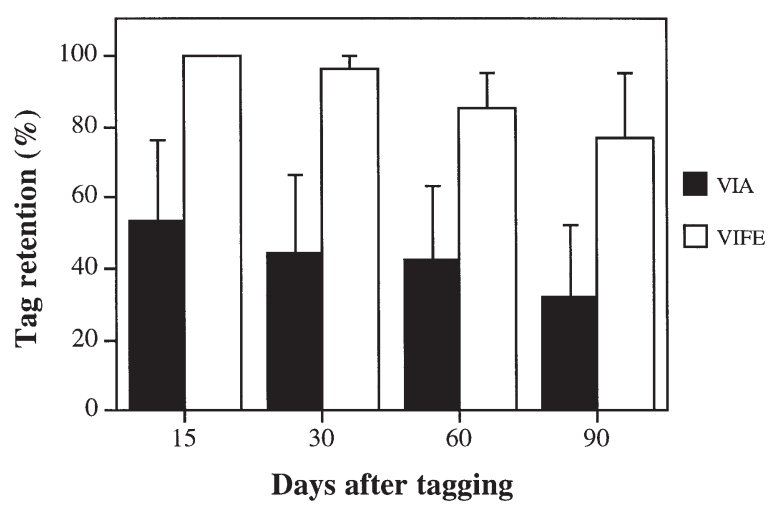

Fig. 1. Percentage (mean $\pm 1 \mathrm{SE}$ ) of visible implant alphanumeric (VIA) tags and visible implant flourescent elastomer (VIFE) tags retained by fish 15, 30, 60 and $90 \mathrm{~d}$ after tagging. Data has been pooled for Girella elevata and Bathygobius cocosensis

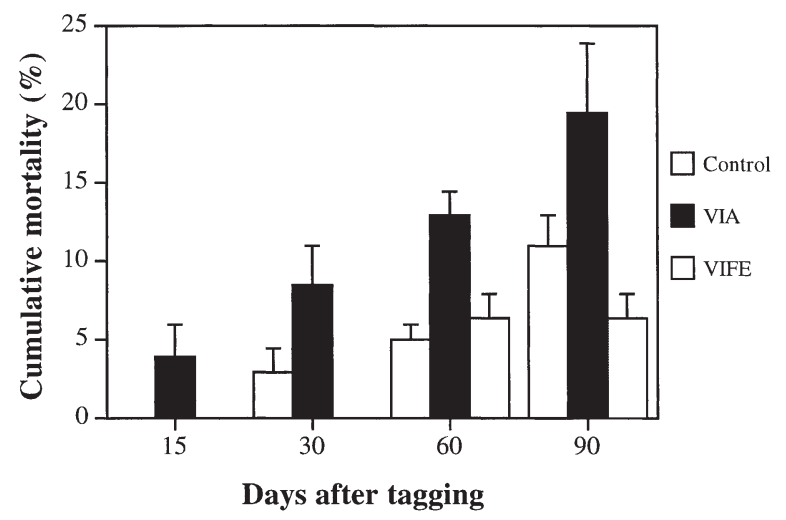

Fig. 2. Percentage cumulative mortality (mean $\pm 1 \mathrm{SE}$ ) of fish $15,30,60$ and $90 \mathrm{~d}$ after tagging with visible implant alphanumeric (VIA) tags, visible implant flourescent elastomer (VIFE) tags, or left untagged (Control)

The main factor influencing tag retention was probably handling during tag inspections, as tags were found on the bottom of containers used to transfer fish from aquaria to the observation laboratory. Kincaid \& Calkins (1992) suggested that tag loss can be highly influenced by excessive handling after implantation where insertion wounds have not properly healed. Although extreme care was taken when handling fish, examination of unhealed wounds indicated that this may be a major source of tag loss even after $90 \mathrm{~d}$. The rate of tag loss of both tag types would probably be far lower in field experiments where tagged fish would not be continually handled. However, some tag losses are to be expected, as VIFE tags can be lost without handling of fish if tags are not inserted correctly (Willis \& Babcock 1998).

Editorial responsibility: Otto Kinne (Editor),

Oldendorf/Luhe, Germany
Some interspecific differences in retention rates for VIA tags were noted, which probably related to differences in fish anatomy and behaviour. For example, tag loss in Girella elevata may have been in part due to the small amount of semi-transparent tissue at the nape, which probably requires a smaller tag to resist movement by muscular contractions. Second, the secretive behaviour of $G$. elevata may also contribute to tag loss as fish were observed rubbing the tag site upon rocks. Conversely, elastomer tags could be injected into a more suitable tag location (i.e. the cheek), thus resulting in higher retention rates. Conversely, Bathygobius cocosensis has ample transparent cheek tissue enabling both VIA and elastomer tags to be implanted further from the insertion point, which probably accounted for high retention rates, particularly for VIA tags.

Acknowledgements. I thank Kirsten Benkendorff for generous use of her aquaria, Jade Butler for assistance in laboratory procedures, Robin Gibson for comments on drafts of this manuscript and Daniel Thompson from Northwest Marine Technology for generous donation of tags. This research comprises a small component of a PhD dissertation by the author funded by an Australian Postgraduate Award. Fish were handled in accordance with the regulations of an animal ethics permit (No. AE99/13).

\section{LITERATURE CITED}

Blankenship HL, Tipping JM (1993) Evaluation of visible implant and sequentially coded wire tags in sea-run cutthroat trout. N Am J Fish Manag 13:391-394

Dewey MR, Zigler S (1996) An evaluation of fluorescent elastomer for marking bluegills in experimental studies. Prog Fish-Cult 58:219-220

Forrester GE (1995) Strong density-dependent survival and recruitment regulate the abundance of a coral reef fish. Oecologia 103:275-282

Gibson RN (1999) Methods for studying intertidal fishes. In: Horn MH, Martin KLM, Chotkowski MA (eds) Intertidal fishes: life in two worlds. Academic Press, San Diego, p 7-25

Griffiths SP (2000) The use of clove oil as an anaesthetic and method for sampling intertidal rockpool fishes. J Fish Biol 57:1453-1464

Halls AS, Azim ME (1998) The utility of visible implant (VI) tags for marking tropical river fish. Fish Manag Ecol 5:71-80

Kincaid HL, Calkins GT (1992) Retention of visible implant tags in lake trout and Atlantic salmon. Prog Fish-Cult 54: 163-170

Malone JC, Forrester GE, Steele MA (1999) Effects of subcutaneous microtags on the growth, survival, and vulnerability to predation of small reef fishes. J Exp Mar Biol Ecol 237:243-253

Willis TJ, Babcock RC (1998) Retention and in situ dectectability of visible implant fluorescent elastomer (VIFE) tags in Pagrus auratus (Sparidae). NZ J Mar Freshw Res 32:247-252 